\title{
A social-ecological framework for analyzing and designing integrated crop-livestock systems from farm to territory levels
}

\author{
Marc Moraine*, Michel Duru and Olivier Therond \\ Institut National de la Recherche Agronomique (INRA), UMR 1248 AGIR, Chemin de Borde Rouge, CS 52627, \\ 31326 Castanet-Tolosan cedex, France \\ *Corresponding authors: marc.moraine@gmail.com or olivier.therond@toulouse.inra.fr
}

\begin{abstract}
Integrated crop-livestock systems are often considered a promising way to address agricultural sustainability issues. Many authors claim that complementarities and synergies between crops and livestock can improve nutrient cycling and delivery of ecosystem services (ES) in agricultural systems. They have analyzed effects of interactions at the farm level and affirmed the potential advantage of developing crop-livestock interactions at the territory level. However, potential benefits of developing synergies beyond the farm level have not been clearly identified. Thus, we developed a conceptual framework that can be used to analyze, design and perform integrated assessment of crop-livestock systems at the territory level. To address crop-livestock interaction issues, we define it as a social-ecological system called the territorial crop-livestock system (TCLS). The ecological system is represented as three interacting components, crops, grasslands and animals, allowing description of various land uses and their potential effects on nutrient cycling and ES. The social system, represented as farmers interacting with natural-resource managers and agro-food chain actors, determines land use and the nature and intensity of ES delivered. We highlight the importance of coordination and learning among actors to support implementation of complex adaptive systems such as TCLSs. We illustrate the expressive power of our conceptual framework through development of a generic typology of crop-livestock systems. Then we show how our conceptual framework can be used as an intermediary object with stakeholders in participatory design approaches. We illustrate this process by representing four archetypal TCLSs. We provide an example of the design approach implemented in Southwestern France to address severe recurrent water shortages, which includes analysis of land use in the current crop-livestock system and the associated key metabolic and ES issues, identification of options for change and multi-criteria analysis of these options. We conclude that this framework shows great potential to support development of sustainable farming systems at the territory level.
\end{abstract}

Key words: crop-livestock integration, ecosystem services, social-ecological system, landscape design, nutrient cycling, multi-criteria analysis

\section{Introduction}

Agricultural production systems that combine animals and crops have existed for 8-10 millennia (Russelle et al., 2007). Originally, these systems allowed animals to use non-arable zones and crop residues, which increased fertility of arable soils with animal wastes and provided a variety of plant and animal products. In the 20 th century in industrialized countries, mechanization led to the disappearance of draft animals, while intensive use of mineral fertilizers increased agricultural production without dependence on animal waste. At the same time, long and diversified rotations, the main method for managing pests, were shortened and simplified due to pesticide use (Schott et al., 2010). These changes led to simplified and standardized production methods and specialized farming systems and regions as a function of their comparative advantages. In many regions of developed countries where crops are grown, prevalence of livestock systems generally declined due to this specialization process (Schiere et al., 2002; Russelle et al., 2007; Wilkins, 2008). Livestock systems are now concentrated in zones organized into large livestock chains (e.g., milk production in Brittany or Denmark), in regions with limits to mechanized plowing and in mountainous zones that produce high-added-value cheese (e.g., Alpine regions of France, Swiss and Italy). The dynamics of specialization cannot be disassociated from the use of inputs, 
fossil energy and often irrigation water, which make these hyper-specialized systems possible (Mazoyer and Roudart, 2006). The FAO's Livestock's Long Shadow report (FAO, 2006) indicated that continuing the current trend of livestock intensification and specialization in industrialized countries is not sustainable due to its impacts on water resources, climate change and ecosystems.

Recently, many reviews (Lemaire, 2007; Russelle et al., 2007; Hendrickson et al., 2008) and special issues (Franzluebbers et al., 2014) have listed the benefits of farming systems that combine crops and livestock when their integration is suited to soil and climate conditions. These studies highlight that developing crop-livestock interactions mainly provoke land-use issues. Bell and Moore (2012) categorized possible interactions between crop and livestock production in space (co-location versus segregation) and time (synchronization versus rotation). Also, recent reviews list expected benefits at the farm level in a wide range of regions: the USA (Sulc and Franzluebbers, 2014), North and South America (Franzluebbers et al., 2013), Australia (Bell et al., 2014), Europe and South America (Bonaudo et al., 2014). These studies have mainly focused on resource-use efficiency, improved nutrient cycling, increased soil fertility by including legumes and grasslands in cropping systems and diversified production to stabilize yields and decrease economic risks. Crop-livestock integration represents a model of 'eco-efficient' agriculture to reduce negative environmental outcomes (Wilkins, 2008). Thornton and Herrero (2014) showed the potential of crop-livestock integration to increase resilience of production systems to climate change in developing countries. Biological diversity were highlighted by Liebman and Schulte (2015) as a great way to insure resilience of agroecosystems. Risk mitigation and ability to match land use to land capacity have also been explored (Sumberg, 2003; Herrero et al., 2010) as well as potential for soil and water resource preservation. Recent literature has recognized crop-livestock systems as an acceptable way to develop ecosystem services (ES) to reduce use of exogenous inputs (Bonaudo et al., 2014) and support ecological modernization of agriculture (Horlings and Marsden, 2011). Duru and Therond (2014) pointed out that most studies investigating types of crop-livestock integration considered management options without explicitly examining whether they improve nutrient cycling and input-use efficiency (i.e., the 'metabolism' of the system) or develop ES.

A majority of studies have analyzed environmental or economic performances of crop-livestock integration at the farm level (Ryschawy et al., 2012; Botreau et al., 2014). Considering the great difficulties in reintroducing animals to specialized field-crop farms, some have suggested investigating the potential of integrating crops and livestock among farms, i.e., at the territory (or landscape) level (Lemaire et al., 2014; Peyraud et al., 2014;
Soussana and Lemaire, 2014). By 'territory', we mean the geographic level at which local agricultural and natural resource management issues are managed. Developing interactions between specialized crop and livestock farms at the territory level raises important methodological issues and conceptual gaps regarding ways to analyze and design integrated crop-livestock systems (ICLS). Tanaka et al. (2008) described the difficulty of integrating multiple objectives and analyzing trade-offs between performances in such an experimental approach. Randrianasolo et al. (2010) showed the importance of ex-ante analysis and multi-criteria assessment to design ICLS.

Methodological challenges of developing ICLS at the territory level, hereafter called territorial crop-livestock systems (TCLS), are numerous. An analytical framework is necessary to identify current farming systems and advantages and issues of developing crop-livestock interactions at the territory level. A conceptual framework to support design of the spatial distribution of crop-livestock interactions in the landscape and the transfer of raw resources between farms (e.g., livestock waste and forage) is also required. Because development of croplivestock interactions at the territory level will require reorganization within farms, this framework should also account for these within-farm changes. Breakthrough innovations are often necessary in such a design approach that includes both farming systems and territory, and consequently involves different stakeholders (Nassauer and Opdam, 2008; Meynard et al., 2012; Moraine et al., 2014a). This entails simultaneous consideration of individuals and collective action, social learning and adaptation to change (Bretagnolle et al., 2011). Therefore, design of TCLS must consider the ecological and socio-economic conditions of their implementation. The focus on analysis of relationships between farming systems and agricultural-landscape dynamics anchors this work in the scientific field of landscape agronomy (Rodríguez-Ortegua et al., 2014) and landscape design (Nassauer and Opdam, 2008).

This paper presents an original conceptual framework of TCLS. It was built to design ICLS in contrasting European case studies and updated on the basis of this experience (see Moraine et al., 2014a). In this updated framework, TCLS are presented as social-ecological systems in which crop-livestock integration among animals, grasslands and crops enhance metabolic functions, ES and depend on stakeholder coordination at the territory level. This framework allows one to analyze existing forms and levels of crop-livestock integration, to design TCLS and to perform integrated assessment of the designed system. It encompasses social-coordination issues surrounding development of TCLS systems. We illustrate and discuss the expressive power (i.e., the breadth of ideas that can be represented) of our conceptual framework to: (i) develop a generic typology of crop-livestock systems, and (ii) support the three steps of a TCLS design process: diagnosis, design and 
assessment, conducted in a participatory research project in Southwestern France.

\section{A Conceptual Framework to Analyze Crop- livestock Integration}

\section{Biophysical components, flows and processes of crop-livestock integration}

Core interactions among animals, grasslands and crops. At farm or territory levels, crop and livestock production can be structurally independent or interact over space and time. Characterizing key interactions within these systems is primarily a matter of describing land use, considering direct (e.g., biomass consumption and deposition of animal waste) and indirect (e.g., manure release) effects of animals (Bell and Moore, 2012). In these systems, medium- to long-term grasslands are a land-use type with a particular role in delivering key ES (Bretagnolle et al., 2011; Lemaire et al., 2014; Rodríguez-Ortegua et al., 2014). Thus, to represent land use in TCLS it is particularly important to consider spatiotemporal interactions between animals, grasslands and crops. In our conceptual framework, they are represented as three 'spheres' that interact over space and time to varying degrees (Fig. 1). Crop and grassland spheres, which correspond to two major agricultural production areas, are composed of a range of species or species mixtures with specific functions. The animal sphere corresponds to groups of animals and can determine how the two other spheres are used. Small and large woody species are not excluded from the crop and grassland spheres. Their presence may vary, ranging from lone trees or hedgerows to agroforestry systems or the grazing of moors. Graphically, overlapping areas of spheres represent direct interactions in space, either simultaneously (e.g., grasslands grazed by animals) or over time in the form of a sequence (e.g., grasslands in rotation with crops). The grassland sphere includes cut or grazed permanent grasslands (overlapping with the animal sphere) and grasslands in rotation that are mowed (overlapping with the crop sphere) or mowed/grazed (overlapping with both the crop and animal spheres). The crop sphere includes cash crops and crops destined for animals. This representation allows distinction among management practices such as with dual-purpose crops, when crop allocation may be modified by a tactical switch from one use to the other. Additionally, the destination of cash crops does not exclude the use of by-products such as straw for feeding livestock or crop-residue grazing. The animal sphere is composed of different groups of animals whose species, breed or performance level should be relatively homogeneous. Characteristics of each animal group or combination of them determine the type and quality of resources that it can consume as well as the quality of its wastes. This framework can be used to represent crop-livestock interactions both at the farm level and the landscape level. Improving the sustainability of agricultural systems by developing TCLS requires identifying ways to improve system metabolism or ES provision (Dumont et al., 2013), i.e., analyzing the metabolism of material flows and biodiversity effects on ES at farm and landscape levels.

Metabolic analysis of material flows. Several studies (Carvalho et al., 2010; Dumont et al., 2013; Botreau et al., 2014) highlight the importance of improving the metabolic functioning of livestock systems to improve sustainability of animal production. A crucial issue in ICLS is increasing resource-use efficiency and system self-sufficiency and decreasing direct (e.g., nitrate losses) or indirect (linked to input production) pollutant emissions to the environment. Beyond classic agricultural approaches that improve resource-use efficiency by applying a sufficient quantity at the right location and time (Drinkwater and Snapp, 2007), Figuière and Metereau (2012) described how industrial ecology can inspire the design of self-sufficient agricultural systems based on recycling waste from one subsystem to another. Recycling principles already exist in numerous case studies of ICLS (Schiere et al., 2002; Giller et al., 2006; AcostaMartinez et al., 2010; Randrianasolo et al., 2010; Chardon et al., 2012) and extend to more complex practices, such as grazing green-manure crops (Martens and Entz, 2011). Grazing, via deposition of animal waste, returns most of the nutrients removed by animals, although it may induce losses to the environment due to grazing heterogeneity (Piñeiro et al., 2010; Soussana and Lemaire, 2014).

Accordingly, improving ICLS metabolism requires analyzing, designing and managing flows of key exogenous (inputs) and endogenous materials (waste of a subsystem) between the main components of the three spheres (Fig. 1). For example, animals on a farm with confined pigs would be large sources of nitrogen $(\mathrm{N})$ (stocked urea and feces) and use a large amount of carbon (C) (straw and feed). Another farm with only cereal cropping would have the opposite profile: a large source of grain and straw using a large amount of $\mathrm{N}$ fertilizers. In this theoretical example, TCLS composed of these two types of farms could improve $\mathrm{C}$ flows (fixation through photosynthesis of cereals and consumption by pigs) and $\mathrm{N}$ recycling (use of pig manure as fertilizers) but still would be deficient in endogenous $\mathrm{N}$ supply (typically brought by protein crops or legume-based grasslands).

Biodiversity approach for the development of ES. The concept of ES was developed and widely diffused through the Millennium Ecosystem Assessment (2005). The nature of services rendered to human societies are most often classified as provisioning (nutritional, material and energetic outputs from ecosystems), regulating (regulation of natural processes such as erosion and pest control) and cultural services (providing spiritual, inspirational and educational experience). Focusing on interactions between ES and agriculture, Zhang et al. (2007) and 


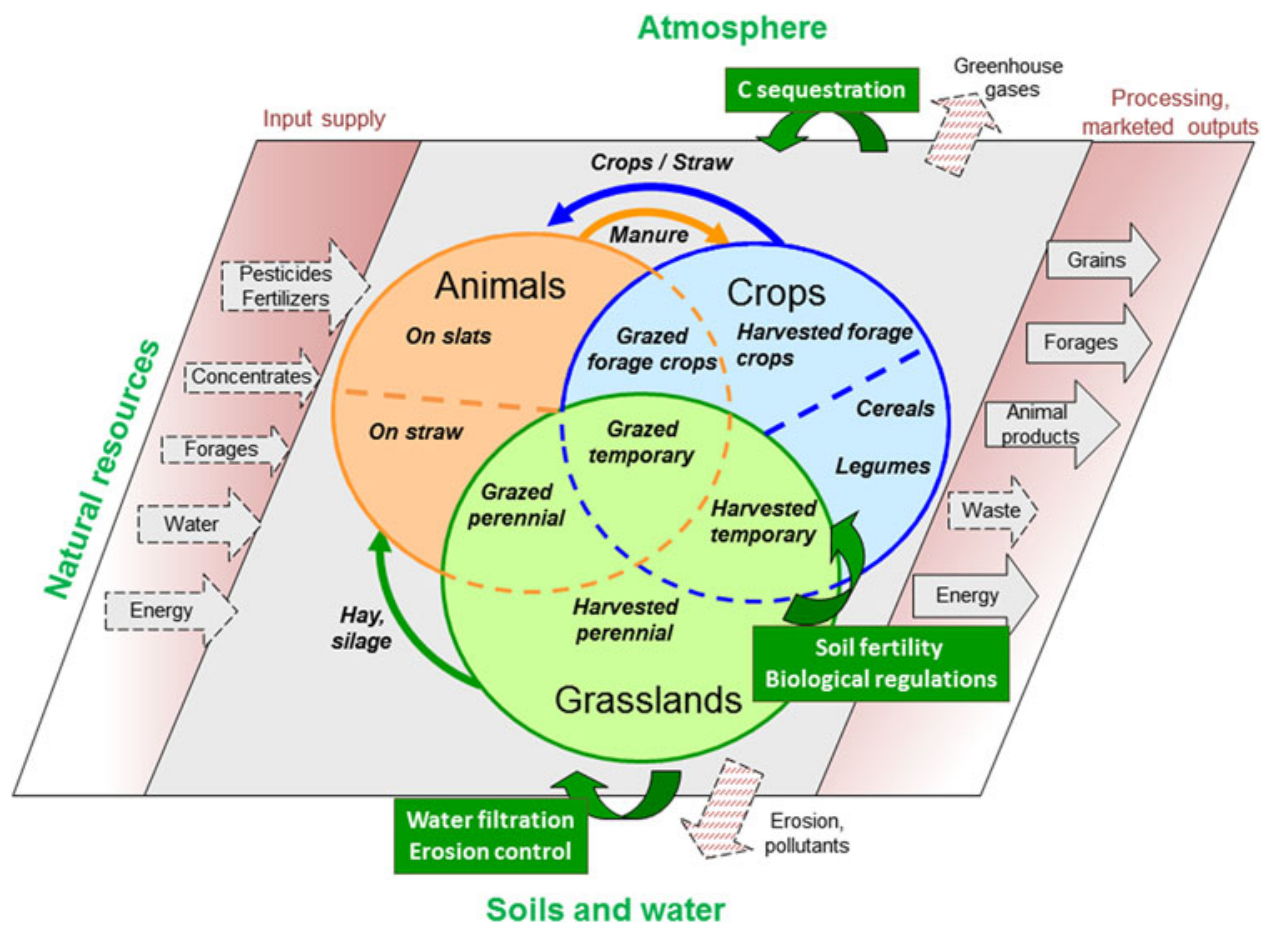

Figure 1. Biophysical components, key material flows and key ecosystem processes in an integrated crop-livestock system. For illustration, the three spheres and overlapping areas have similar dimensions. By varying their sizes and degrees of overlap, it is possible to represent the structure of a wide range of crop-livestock systems. Interactions among the three spheres determine the delivery levels and resilience of key ecosystem services based on associated ecosystem processes (large semi-circular arrows). One challenge of crop-livestock integration is to drastically reduce input flows and emissions to the environment.

Swinton et al. (2007) highlighted that agriculture both provides and receives ES. Similarly, Le Roux et al. (2008) categorized services into 'input services' and 'output services'. Input services correspond to regulating services (e.g., soil fertility and biological regulation) delivered to the farming system that promote its natural productivity and enable it to depend less on marketed inputs (e.g., mineral fertilizers and pesticides) and irrigation water. Output services include services provided by agriculture to society. They correspond to provisioning, regulating and cultural services either marketed (e.g., cash crops and milk) or not directly marketed (e.g., $\mathrm{C}$ sequestration and cultural services). The three-sphere conceptual framework analyzes land use (on farms and in the landscape) and the key expected input ES: soil fertility and biological regulation of pests and diseases, and output ES (Fig. 1).

The nature and spatial distribution of crops, grasslands, animals and semi-natural habitats can be adapted to enhance biodiversity and increase delivery of ES at field and landscape levels (De Groot et al., 2010; Power, 2010; Díaz et al. 2011; Kremen et al., 2012). Crucial features of TCLS to deliver ES include:

- Spatial pattern, crop-grassland sequences and grassland management (Franzluebbers et al., 2014; Soussana and Lemaire, 2014);

- Proportion of crop rotations composed of legumes (Altieri, 1999) or mixed (or multiple) crops such as cereal-legume mixtures (Gaba et al., 2014);
- Botanical composition of grasslands, in particular the proportion of legumes (Lemaire et al., 2014);

- Grazed areas, including permanent grasslands, temporary grasslands in rotation, intercrops or crop residues (Wardle et al., 2004; Drinkwater and Snapp, 2007; Soussana and Lemaire, 2014);

- Area and intensity of animal manure application to field crops (Diacono and Montemurro, 2010; Soussana and Lemaire, 2014).

These features influence biodiversity levels and trophic chains above the soil (e.g., birds and insects) (Power, 2010) and within the soil (e.g., earthworms, bacteria and fungi) (Koohafkan et al., 2011), which determine soil fertility and biological regulations: pollination and control of weeds, pests and diseases (Ratnadass et al., 2012). C sequestration, water retention and erosion control also depend on these variables (Garbach et al., 2014).

Regarding development of TCLS, main motivations of farmers may be to promote input services to reduce their dependence on marketed inputs (e.g., fertilizers and pesticides), with expected or unexpected positive side-effects on output services, especially regulation or cultural services. The great challenges regarding ES of developing TCLS may thus be to develop soil fertility and beneficial biological regulations by developing effective crop-livestock interactions. 


\section{Social components and dynamics of crop- livestock integration}

The TCLS as a social-ecological system. Development of a TCLS is based on promoting direct and indirect (via intermediaries) interactions between farms. These interactions depend on economic, institutional and social resources: infrastructure, markets, institutions and social capital of people involved directly or indirectly in the functioning of this system. Accordingly, a TCLS can be conceptualized as a social-ecological system (Cabell and Oelofse, 2012) in which the social system influences how land is used and managed, as well as the nature of ES it delivers (Díaz et al., 2011; Schouten et al., 2012; Poccard-Chapuis et al., 2014). As mentioned above, the two main types of ES at stake in TCLS are services from ecosystems to farmers and to society (Fig. 2).

Social resources and stakeholder interactions in TCLS. Depending on the type of TCLS, different actors may be involved. If the TCLS is driven by the desire of crop and livestock farmers to exchange products, then it may be based either on direct exchanges between farmers or intermediated by supply chains in larger and more structured exchanges. Direct exchanges between farmers require strong coordination to organize collective distribution of work, resulting in better inter-personal knowledge and dynamic social exchanges (Swinton et al., 2007; Díaz et al., 2011; Klerkx et al., 2012).

Social exchanges among partners of the TCLS are crucial for developing shared objectives, ideas, practices and experiences. These latter are necessary to strengthen trust, acquaintanceship and social learning (Armitage et al., 2008; Houdart et al., 2011) among farmers, and to allow stakeholders from different professional worlds, such as specialized crop and livestock farmers, to work together, and form 'communities of practice' (Pahl-Wostl and Hare, 2004; Armitage et al., 2008; Newig et al., 2008). Circulation of information could enhance the capacity to collectively adapt to changes in the social-ecological system (Armitage et al., 2008; Biggs et al., 2012), e.g., organization of cropping plans and tactical adaptation to annual conditions. The combination and sharing of perceptions and knowledge about the issues among stakeholders may help them find compromises and avoid uncoordinated actions or disagreements in case of controversies about the management solutions (Klerkx et al., 2012; Moraine et al., 2014a). Farmers may have to share investments in equipment (e.g., to spread manure, harvest temporary grassland or dry hay) or hire workers together (e.g., when developing a new business). Such collective organization requires adapted governance, including clear rules for exchange management (including forms of contracts between farmers and collective regulation of prices of products). Farmers' groups can be either informal functioning only on inter-personal knowledge, or structured into institutions such as associations, companies or groups of economic interest. This institutionalization of groups may improve their capacity for action (e.g., facilities for collective investments or obtaining subsidies), resulting in an empowerment of farmers and increased autonomy from other actors, e.g., animal food supply chains. When supply chain actors mediate exchanges between farmers, they can provide logistics for organizing collection, storage and transport of products. They can also contribute to the process and marketing of products through the development of local-origin labels and local selling points.

Design of TCLS can also be driven by the need to manage natural resources at a local level (e.g., water management at the watershed level). In this case, a wide range of stakeholders can be involved (Duru and Therond, 2014): local policy makers involved not only in land-use planning and management of environmental issues, but also environmental, citizen and tourism associations.

Coordination among stakeholders of TCLS is essential to optimize technical and organizational changes. It must overcome the transaction costs and constraints identified in the scientific literature (Hendrickson et al., 2008; Horlings and Marsden, 2011), primarily the complexity of developing new crops and animal feeds and exchanging products, especially in livestock farms, where workloads are already critically constraining (Ryschawy et al., 2012; Lemaire et al., 2014). Under these conditions, several economic and social benefits can be expected from TCLS.

Construction of local diversified markets for crop and livestock systems within territories could decrease the risk of income variability (Bell et al., 2014; Franzluebbers et al., 2014). Livestock systems that require feed represent an alternative to selling crops in conventional markets and could mitigate a decrease in quality following a technical problem (e.g., fungal contamination) or meteorological event, as well as provide a market for by-products such as cereal bran. Organizing local exchanges between crop and livestock systems favors traceability of production and provides the opportunity to create local production labels and support direct sales (Moraine et al., 2014a).

Development of TCLS may allow reallocating activities within a location to gain comparative advantage, increase investment return, and/or increase resource-use efficiency (Wilkins, 2008). For example, producing irrigated forage in areas with high agronomic potential, where water is available and accessible at low prices, and transferring it to livestock farms in the same territory that are not located in these zones could preclude the construction of expensive water reservoirs (Moraine et al., 2014b).

Indirect benefits of TCLS can be expected from location of agricultural activities in the territory and integration in public policies. Land-use diversification with grazing animals could promote tourism activities and improve the image of agriculture. New agricultural supply chains and activities could contribute to local economic dynamics. Public-policy support of TCLS development may be possible when it addresses local and/or global 


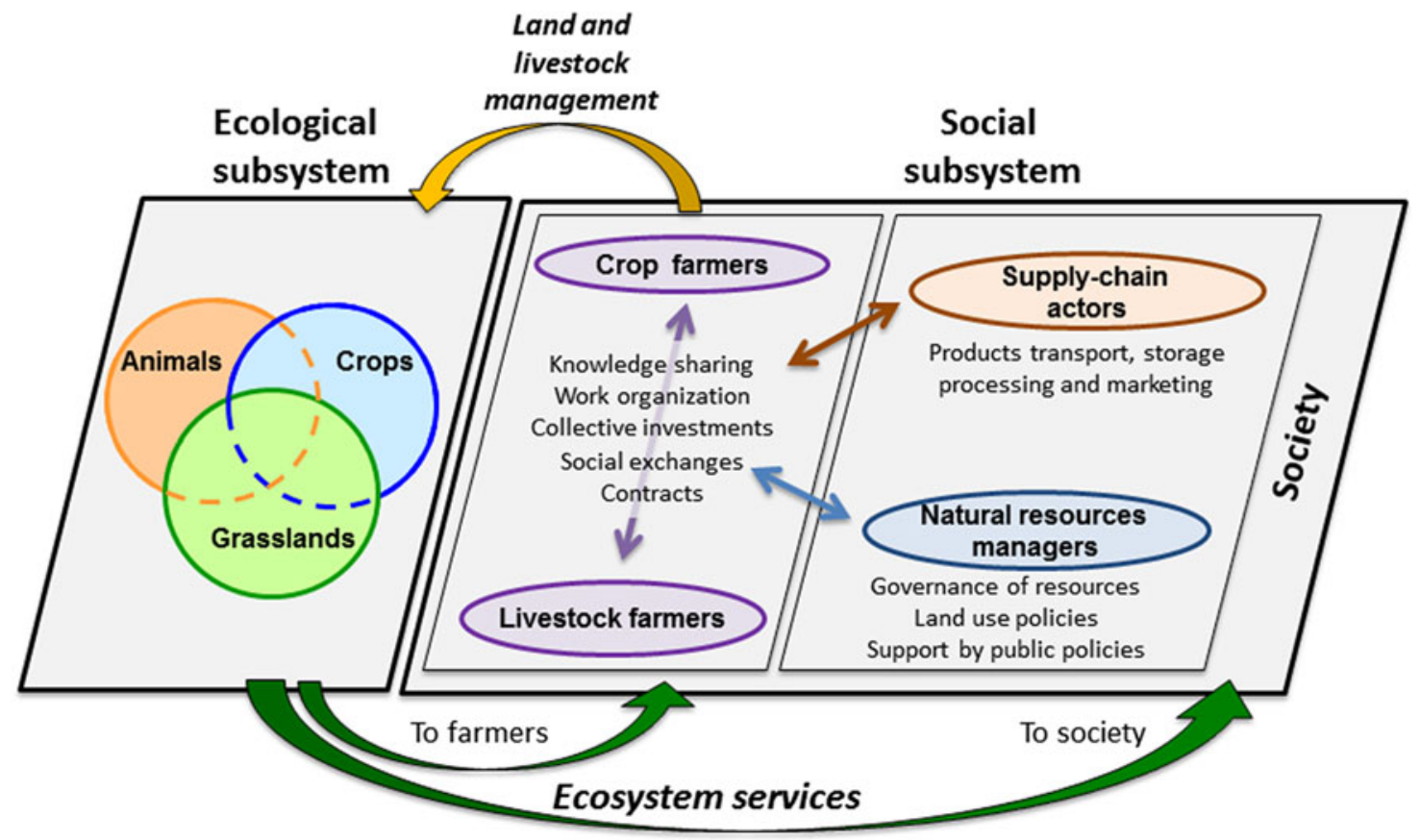

Figure 2. Interactions between social and ecological subsystems in a territorial crop-livestock system. Interactions between agricultural stakeholders determine land-use practices and in turn ecosystem services delivered either to civil society or to farmers. Straight arrows represent key interactions analyzed or designed in a territorial crop-livestock integration perspective.

sustainability challenges by reducing use of synthetic inputs and natural resources. For example, in the European Union, the greening of the Common Agricultural Policy recommends diversity in crop patterns and maintaining a certain proportion of grasslands at the territory level. Local development policies could also support adoption of TCLS through subsidies for collective investments. Furthermore, through lobbying, organization of TCLS stakeholders could facilitate their consideration in public policies, e.g., adapting laws to facilitate exchange of lands or diversify farm activities for cereal farmers hosting animals on their land (Moraine et al., 2014a).

\section{Multi-criteria assessment of TCLSs}

Defining the main components and processes of ecological and social subsystems of TCLS helped us develop a framework for ex-post multi-criteria assessment of current TCLS or ex-ante assessment of those designed (Table 1). Assessment criteria were selected according to the object and recipients of assessment (Carof et al., 2013; Botreau et al., 2014). The objects of assessment were crop-livestock interactions at the territory level. The recipients of assessment were local stakeholders interested in developing TCLS to address local sustainability issues, as well as researchers who wish to better understand the process, benefits and limits of TCLS. Policymakers seeking to develop sustainable agricultural systems could also be recipients of this assessment.

Logically, this multi-criteria framework distinguishes ecological and social systems, main domains of crop-livestock integration, main processes and assessment criteria for each process. For the ecological system, it considers system metabolism (section 'Metabolic analysis of material flows') and ES (section 'Biodiversity approach for the development of ES'). For the social system, it distinguishes technical management, knowledge management, economic performances and social inclusion of TCLS (section 'Social resources and stakeholder interactions in TCLS'). Based on feedback analysis from 12 case studies for which a qualitative assessment was made (Moraine et al., 2014a), we identified key criteria and indicators to investigate crop-livestock interactions from farm to territory levels. For each proposed criterion, Table 1 provides examples of possible assessment indicators. The multi-criteria framework is generic and adaptable. It can be adapted to the context of TCLS development; especially for local sustainability issues (see section 'Designing TCLS'). This framework highlights the diverse issues that should be considered when designing TCLS.

\section{Use of the Conceptual Framework for Analysis and Participatory Design of Crop- livestock Systems}

\section{Principles}

Analyzing and designing a TCLS that is adapted to local or global challenges requires accounting for the complex constraints that arise on farms and in the territory (Cutts et al., 2011). Intermediary objects, such as our conceptual framework, can help participants involved in the 
Table 1. Biophysical and social processes, associated criteria of crop-livestock integration and examples of indicators. The indicators were used to inform criteria in assessment of the Aveyron case study. Each indicator was rated from 'very low' $(-2)$ to 'very high' $(+2)$ and aggregated.

\begin{tabular}{|c|c|c|c|c|}
\hline Subsystem & Domain & Process & Criterion & Indicator \\
\hline \multirow[t]{10}{*}{$\begin{array}{l}\text { Ecological } \\
\text { system }\end{array}$} & $\begin{array}{l}\text { System } \\
\text { metabolism }\end{array}$ & Nutrient cycling & $\mathrm{N}$ inputs/outputs & $\begin{array}{l}\text { Balance of N sinks (cereal crops, animal } \\
\text { protein feed) and sources (legume crops, } \\
\text { grasslands with legumes, animal waste) }\end{array}$ \\
\hline & & & $\mathrm{C}$ inputs/outputs & $\begin{array}{l}\text { Balance of C sinks (animal feed) and sources } \\
\text { (cereal straws, grain, grasslands) }\end{array}$ \\
\hline & Ecosystem services & Soil fertility & Organic manure & Grazing of grasslands \\
\hline & to agriculture & maintenance & application & $\begin{array}{l}\text { Grazing of crop residues } \\
\end{array}$ \\
\hline & & & & $\begin{array}{l}\text { Grazing of immature cereals } \\
\text { Manure spreading on fields }\end{array}$ \\
\hline & & & Symbiotic $\mathrm{N}$ fixation & Legume crops \\
\hline & & & & Grasslands with legumes \\
\hline & & Biological regulation & Diversity of crops at the & Long and diversified crop rotations \\
\hline & & & field level & $\begin{array}{l}\text { Crop mixtures in field } \\
\text { Diversified grasslands }\end{array}$ \\
\hline & & & $\begin{array}{l}\text { Diversity of land use at } \\
\text { the landscape level }\end{array}$ & $\begin{array}{l}\text { Distribution of grasslands in a landscape } \\
\text { Diversification of crop patterns }\end{array}$ \\
\hline \multirow[t]{17}{*}{$\begin{array}{l}\text { Social } \\
\text { system }\end{array}$} & $\begin{array}{l}\text { Technical } \\
\text { management }\end{array}$ & Work management & Workload/work quality & $\begin{array}{c}\text { Use of supply chain capacities for transport, } \\
\text { storage or processing of exchanged products } \\
\text { Collective organization and banks of work } \\
\text { Collective investments to hire workers or } \\
\text { equipment }\end{array}$ \\
\hline & $\begin{array}{l}\text { Knowledge } \\
\text { management }\end{array}$ & $\begin{array}{l}\text { Social learning and } \\
\text { capacity building }\end{array}$ & $\begin{array}{l}\text { Active participation of } \\
\text { partners }\end{array}$ & $\begin{array}{l}\text { Groups for debate and decision } \\
\text { Analysis of farming-system resources and } \\
\text { limits to find complementarities }\end{array}$ \\
\hline & & & Autonomy of farmers & Governance rules among groups \\
\hline & & & & $\begin{array}{c}\text { Organization of farmers' groups into } \\
\text { associations }\end{array}$ \\
\hline & & & $\begin{array}{l}\text { Knowledge } \\
\text { capitalization }\end{array}$ & Exchange of practices and trials \\
\hline & & & Adaptive capacity & $\begin{array}{l}\text { Strategic planning and tactical adaptation to } \\
\text { annual conditions }\end{array}$ \\
\hline & $\begin{array}{l}\text { Economic } \\
\text { performances }\end{array}$ & Economic viability & $\begin{array}{l}\text { Resilience to } \\
\text { biophysical and }\end{array}$ & $\begin{array}{l}\text { Diversification of production, supply and } \\
\text { commercial outlets }\end{array}$ \\
\hline & & & economic risks & $\begin{array}{l}\text { Production systems independent of external } \\
\text { inputs }\end{array}$ \\
\hline & & & & $\begin{array}{l}\text { Long-run contracts between farmers with } \\
\text { clear price conditions }\end{array}$ \\
\hline & & & $\begin{array}{l}\text { Added value of } \\
\text { products }\end{array}$ & $\begin{array}{l}\text { Development of labels for local-origin } \\
\text { products }\end{array}$ \\
\hline & & & & $\begin{array}{l}\text { Direct sales and collective } \\
\text { commercialization }\end{array}$ \\
\hline & & & & Get added value from co-products \\
\hline & $\begin{array}{c}\text { Social } \\
\text { embeddedness }\end{array}$ & $\begin{array}{l}\text { Embeddedness of } \\
\text { agriculture in the }\end{array}$ & $\begin{array}{l}\text { Social acceptability of } \\
\text { agriculture }\end{array}$ & $\begin{array}{l}\text { Development of diversified landscapes } \\
\text { including grazing animals }\end{array}$ \\
\hline & & & $\begin{array}{l}\text { Contribution to local } \\
\text { economic dynamism }\end{array}$ & $\begin{array}{l}\text { Tourism activities linked to landscape } \\
\text { quality }\end{array}$ \\
\hline & & & & $\begin{array}{c}\text { Development of local supply chains and new } \\
\text { activities }\end{array}$ \\
\hline & & $\begin{array}{l}\text { Integration in public } \\
\text { policies }\end{array}$ & $\begin{array}{l}\text { Contribution to local } \\
\text { and global } \\
\text { sustainability issues }\end{array}$ & $\begin{array}{c}\text { Reduction in use of non-renewable resources } \\
\text { Reduction in use of pesticides and mineral } \\
\text { fertilizers }\end{array}$ \\
\hline & & & $\begin{array}{l}\text { Support of public } \\
\text { policies }\end{array}$ & $\begin{array}{l}\text { Subsidies for collective infrastructure or } \\
\text { development of new activities }\end{array}$ \\
\hline
\end{tabular}


design process to decipher this complexity (Steyaert and Jiggins, 2007; Voinov and Bousquet, 2010). As highlighted by Ten Napel et al. (2011), a conceptual model of objects under design stimulates innovative ideas and facilitates articulation of different visions and understanding among multiple stakeholders.

Participatory-design methods for agricultural systems are often organized into three key steps (Martin et al., 2013). The first step specifies or frames the problem, i.e., describes current system functioning and associated multi-domain issues (Blom-Zandstra and Van Keulen, 2008). The second step entails designing new systems. Stakeholders most often express their ideas for change by describing options at different organizational levels relative to the current situation (e.g., changes in land use, work management or outlets). Both steps may be supported by the use of a conceptual model (Moraine et al., 2014a) to represent the current situation and possible options for change using, e.g., cognitive maps at the farm (Vanwindekens et al., 2013) or territory level (Etienne, 2014). The third step allows stakeholders to perform an integrated assessment of designed options for change and identify the ones that seem most relevant. It should also help stakeholders find compromises among objectives (Lovell et al., 2010; Bonaudo et al., 2014).

Our conceptual framework can support these three design steps. It has been used successfully in 12 European case studies to support collective design of TCLS (Moraine et al., 2014a). It was applied either to areas with high constraints (arid and semi-arid Mediterranean areas, cold and humid areas from the UK) or areas with high production potential (arable plains), with or without preexisting initiatives for croplivestock integration. Its representation of land use at territory and farm levels helped stakeholders define functional complementarities among crops, animals and grasslands. It allowed agricultural stakeholders to identify risks and possible difficulties and to reinsure farmers about the benefits of crop-livestock integration. It supported identification and characterization of possible changes and acceptable degrees of change among the components of the TCLS. Use of the conceptual framework in these European case studies demonstrates its utility for generating innovative ideas and systemic design through multi-domain and multi-level options for change. It highlighted the importance of actor coordination and the back-and-forth dynamics that reinforce options available in crop-livestock integration.

\section{Analyzing diversity of crop-livestock systems}

Our conceptual framework can be used to analyze the diversity of existing crop-livestock systems and identify key metabolisms, ES and social issues. As illustration, we present a generic representation of four crop-livestock system archetypes, distinguished according to the degree of spatial and temporal coordination between crop and livestock production or farming systems and the level (farm versus territory) at which they are managed (Fig. 3):

- Type 1: Exchange of materials (grain, forage, straw, manure, etc.) between specialized farms, regulated by the market, in a rationale of 'co-existence'. The issues of price and income stabilization may require the use of contracts. This type of spatially segregated coordination strongly limits expression of ecological benefits of crop-livestock integration.

- Type 2: Exchange of materials between spheres in a rationale of 'complementarity' at the farm or territory level. Crop systems are designed to produce the quantity and quality of crop products required for livestock production (in concentrates, forage, straw, etc.) and to use livestock manure as fertilizer. This type of coordination, in which there is little spatial interaction among the three spheres, could enhance the metabolism of farming systems and input services. They require coordination between stakeholders, from opportunistic exchanges to long-term engagements.

- Type 3: Stronger temporal and spatial interaction among the three spheres in a rationale of 'farm-level synergy': stubble grazing, sacrifice grazing, temporary grasslands in rotations and intercropped forages. The farming system is designed to reduce input use by enhancing a wide range of ES at the local scale.

- Type 4: Stronger temporal and spatial interaction among the three spheres to target 'territory-level synergy'. Strong stakeholder coordination optimizes resource allocation and creates local diversified marketing chains that are adapted to specific characteristics of the territory. In addition, methods for sharing work and networks for learning and exchanging experiences are established. Exchanges within and between farms are organized to decrease input use and benefit farm-tolandscape level ES.

The first two types are the most common in intensive agricultural areas such as Western Europe, where sustainability issues require reconsidering these production models (Hill, 1998; Horlings and Marsden, 2011). Identifying trade-offs between TCLS objectives could help in discussing and ranking their importance to relevant stakeholders. For example, from Type 1 (co-existence) to Type 4 (territory-level synergy), a trade-off exists between management complexity and the ES delivered. Other trade-offs might be identified among ES (Rodríguez-Ortegua et al., 2014; Sabatier et al., 2014). Collective evaluation and ranking are essential to guarantee transparency and thus increase acceptability of newly developed systems.

Most agricultural production systems in developed countries can be described through this typology. Confined livestock production based on external inputs and without crops or grassland, and field-crop systems without livestock can only be part of Type 1 'co-existence'. Diversified systems, such as forage-based livestock 


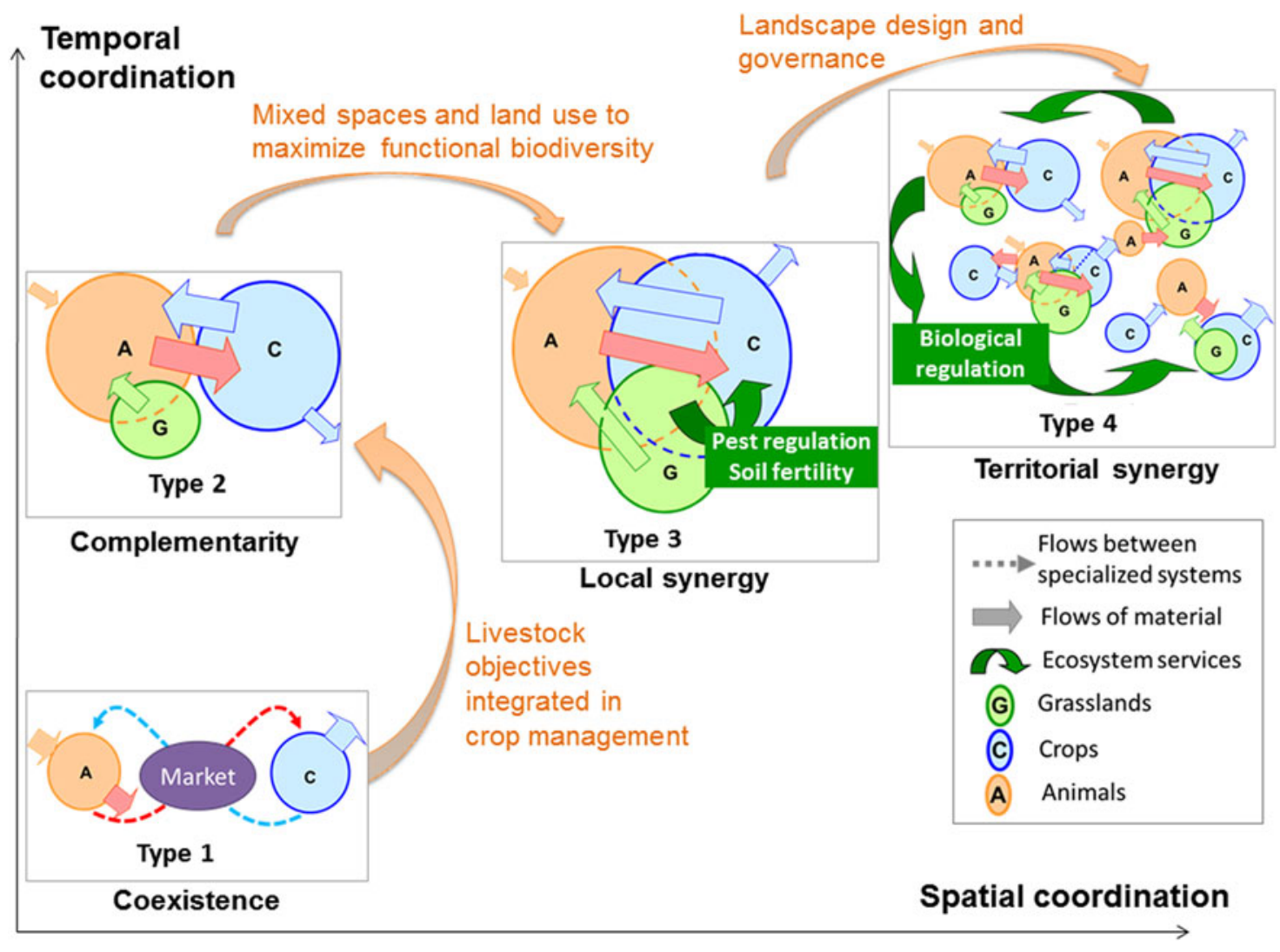

Figure 3. A generic typology of forms of crop-livestock integration according to level of temporal and spatial interaction. Each type has an illustrative name, and key drivers of integration necessary to pass from one type to another are noted.

systems or grassland-based systems with small areas suitable for field crops can belong either to Type 2 or 3 depending on land-use diversity over time. As in Bell and Moore's typology (2012), crops and grasslands can be either segregated or rotated, and grazing may or may not occur. Segregated crops and grasslands without grazing fit within the pure-complementarity rationale of Type 2. Rotated crops and grasslands with grazing may offer greater opportunity for synergistic effects to deliver biological regulation and soil fertility ES, as illustrated in Type 3. Large TCLS involving multiple farm types would offer even more opportunities to organize spatial and temporal diversity and flows. In summary, ICLS typology is useful as an intermediary object to explicitly discuss advantages and issues of crop-livestock integration in different contexts and how to address and achieve these issues. Since few examples actually exist (Moraine et al., 2014b), we examine in the following sub-section a description of Type 4 TCLS.

\section{Designing TCLS}

To demonstrate how our conceptual framework can stimulate and support the design of TCLS, we describe a diagnosis-design-assessment approach implemented in Southwestern France. This study aimed to design a TCLS in the Aveyron River watershed $\left(1560 \mathrm{~km}^{2}\right)$ based on exchanges between specialized field-crop farms and intensive livestock (mainly beef and dairy) farms located in downstream and upstream portions of the watershed, respectively (details in Moraine et al., 2014b). This study was implemented to guide local stakeholders of whether TCLS could deal with severe recurrent water shortages on irrigated farms located downstream and the economic and environmental issues facing downstream and upstream farms. The approach was implemented in three workshops involving stakeholders who represented four positions of interest: (i) public-asset management (rural development and natural-resource management agents); (ii) economic feasibility (supply chains); (iii) landscape, environment and life quality (representatives of water management institutions, nature conservation institutions and environmental associations); and (iv) technical and organizational consistency (farmers and technical advisors).

The first workshop focused on describing current farming systems and their main issues (natural-resource management, biodiversity conservation, economics, work, etc.). Stakeholders described the dynamics of farming-system intensification and their effects on land use, metabolism and ES of farming systems in the two areas. For the upstream area, they explained that development of silage maize in livestock led to progressive abandonment of less productive grasslands and increase of 


\section{Aveyron River watershed}

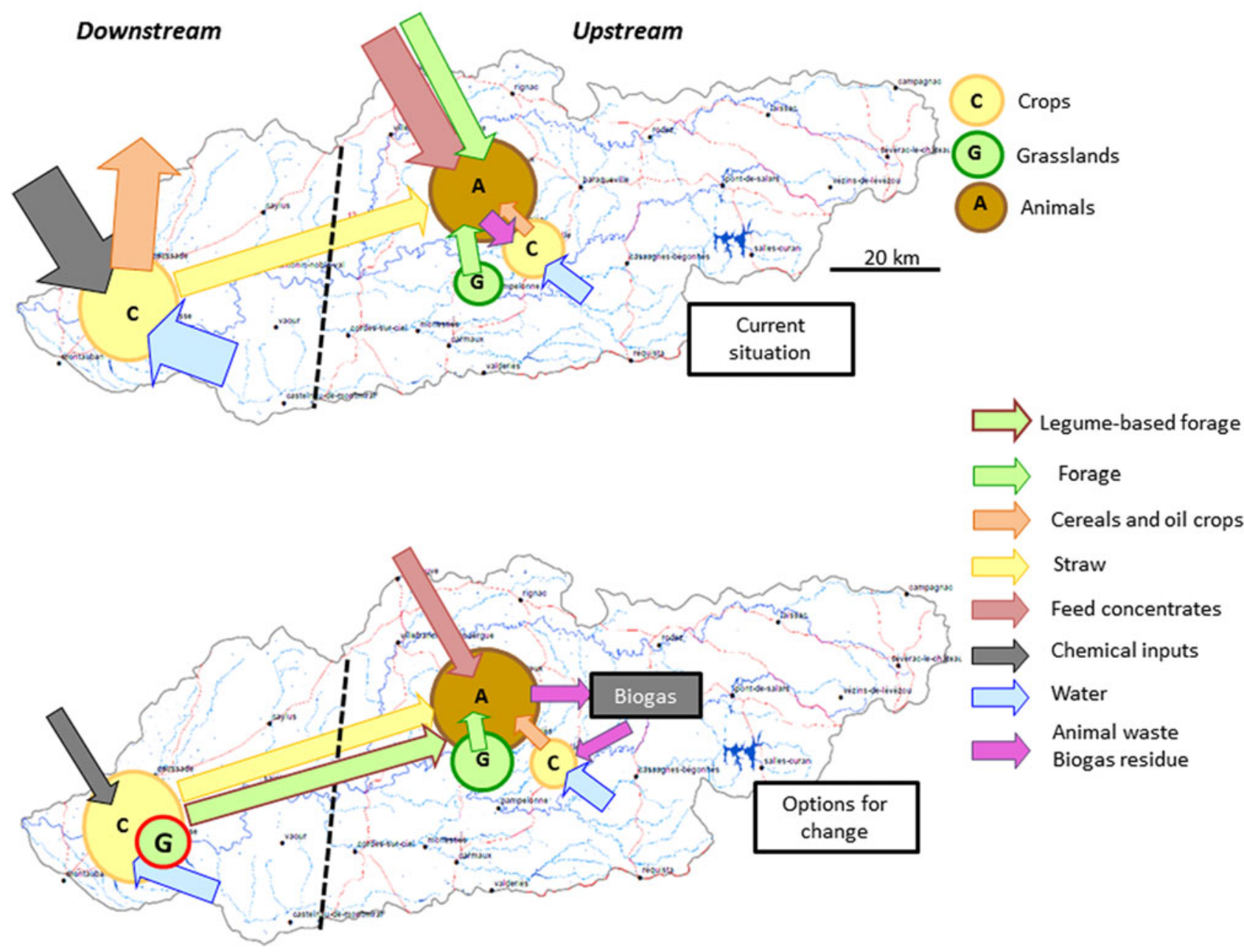

Figure 4. Overview of the current situation and options for change of integration of crop and livestock systems in the Aveyron River watershed (Southwestern France). Arrows represent inputs and outputs of systems. Size of the three spheres (animal, grassland and crop) and arrows represent the importance of each. Overlapping areas between spheres represent levels of spatial interactions between them. In the options for change, introduction of legume-based forage in downstream crop rotations reduces chemical inputs and water use, and produces legume-based fodder that can be sold to upstream livestock systems. Upstream, animal waste can be used to produce biogas and residues are used to fertilize crops upstream or downstream (not represented). Implementing these options for change requires extensive modification to the local governance of agricultural systems.

dependency on imported soybean, cereals and complementary forage (e.g., hay) (Fig. 4a). Liberalization of milk quotas continued to encourage this trend. These feed imports exposed farmers to fluctuations in regional and global agricultural markets. For the downstream area, rainfed (wheat-sunflower rotation) and irrigated (maize monoculture) intensive cropping systems were causing severe soil erosion. Soil chemical, physical and biological fertility declined on almost every farm due to intensive cropping practices. Although these farming systems are considered highly productive and profitable in the short term, sustainability is limited due to high and frequent use of inputs (fertilizers and pesticides) and water, resulting in water pollution and scarcity. Stakeholders explained that few spatial interactions occurred between animals, grasslands and crops on most livestock farms (Type 2). They emphasized that currently few exchanges occurred between downstream and upstream farms since they are connected to regional and global markets through supply chain organizations (Type 1).

The second workshop aimed to identify 'in-the-pipeline' options for change (i.e., already implemented, but on few farms) and innovative options (not already implemented in the territory). It identified innovative practices and potential targets that farmers could implement to address the sustainability issues identified during the first workshop. Our conceptual framework was used to stimulate thinking and organize ideas for developing a TCLS. Stakeholders suggested introducing protein crops and temporary legume-based grasslands in crop rotations in the downstream area to feed upstream livestock 
systems and reduce pesticide and fertilizer use in downstream farming systems (Fig. 4b). By diversifying maize monocultures (e.g., alfalfa in rotation with maize and irrigated only when water is available), these changes would also reduce irrigation-water withdrawals and waterdeficit problems. They emphasized that such cropping system diversification would require changes in governance, mainly the involvement of supply chains, to resolve technical issues (e.g., alfalfa harvesting and drying) and market issues, i.e., developing a stable croplivestock market that meets the needs of both types of farms. Stakeholders considered that offering suitable fodder and grains from downstream to upstream livestock systems might enable the latter to reconsider land use by either limiting replacement of grasslands with maize or replacing maize on less-suitable soils with grasslands. Another proposal was to produce biogas with upstream animal waste and use biogas residue to fertilize crops upstream. This option by itself could recruit other waste providers to ensure continued biogas production over time. In using our conceptual framework, stakeholders shared their needs for technical learning (e.g., to manage new crops, feeds and residues) and coordination among them. They also highlighted the importance of connecting multiple small projects to develop a consistent agricultural-development project at the territory level.

In the third workshop, we used the multi-criteria analysis framework to assess impacts of options for change and compare them with those of the current situation at farm and landscape levels (see Supplementary Material 1 for the complete multi-criteria analysis of the TCLS). Participants were asked to rate criteria qualitatively, and discussion followed to reach consensus on a final rating, with possible options when consensus was not reached. According to stakeholders, most criteria improved with design of a TCLS. Particular advantages of the TCLS were expressed for nutrient cycling, soil-fertility maintenance and biological regulation. Positive impacts were estimated for resilience to biophysical and economic risks, added value of products, social learning and capacity building, retention of agriculture in the territory and integration in public policies. The TCLS designed was rated neutral for workload and difficulty, partner participation and farmer autonomy. Only organic manure application was considered of lower quality in the TCLS, because biogas residues were considered less beneficial for soils than fresh manure.

To strengthen credibility of the TCLS designed and promote concrete changes in farming systems, further quantitative assessment was considered necessary, either by simulation with computer models or by on-farm trials of new practices. Environmental performance, primarily carbon footprints of certain technical options such as manure transport (MacDonald et al., 2009), would also have to be assessed through suitable methods, such as life cycle assessment (Poeschl et al., 2012). Social performance, dynamics of knowledge exchange and development of new activities would be difficult to simulate or test at a small scale, but could be implemented progressively with appropriate facilitation and farmer participation.

\section{Conclusion}

ICLS have experienced renewed interest as a potential way to address challenges of resource depletion and negative impacts of agriculture in cropping and livestock systems. Since literature has focused on field and farm levels, we developed a conceptual framework that can assist stakeholders in designing ICLS at the territory level (TCLS). A goal of TCLS is to improve farmingsystem metabolism and provision of specific ES in a wider geographic setting. Enhancing ES requires managing material and energy flows and the spatial and temporal organization of agricultural practices at the territory level. This increased complexity requires developing adapted governance based on participation and social learning. Coordination of stakeholders determines the acceptability and final implementation of a TCLS.

Considering crop-livestock integration as an object of design is in itself innovative. For many stakeholders, TCLS may exist, but not necessarily through design like a cropping system. Our approach focuses on key processes that determine the sustainability of crop-livestock systems and introduces the territory level to enable complementarities and synergies between activities. Designing land-use and management practices to intensify these ecological processes requires changing the scale and objects of reflection, first for farmers, but also for the technical advisors and other stakeholders, including researchers, involved in various disciplines. In this sense, our conceptual framework acts as an intermediary object to stimulate and structure analysis of the issues, develop a portfolio of proposed options for change at farm and territory levels and combine them to design an entire TCLS. Overall, the purpose of this design process is to support interactions between stakeholders to foster collective decisions and governance within a social-ecological system.

Due to the organization of agriculture (farm size, distances between farms and between farms and consumer areas) and close relations between agricultural practices and environmental issues (e.g., direct competition between local water users), our scope of the issues and solutions presented has been Europe-focused. But the methodological approach and tools, already applied in a great diversity of situations, can be used and adapted to other contexts across North and South America, Australia, Africa and Asia.

Further research that performs and evaluates design processes with stakeholders is necessary. Analyzing the constitution of stakeholders' groups, the reasons for their involvement, and the type of TCLS they conceive 
would provide a rich picture of possible futures for diversified and resilient agricultural systems. A subsequent step, such as participatory design processes, could be expanded with computer-based models to quantify fluxes of raw materials and nutrients. This would complement multi-criteria analysis assessing potential effects of the options for change. Assessment results will enable identification of trade-offs, expression of stakeholders' preferences and discussion about uncertainties.

Acknowledgements. This work was performed with the support of the Tata-Box project (Territorial Agroecological Transition in Action: a tool-Box for designing and implementing a transition to a territorial agroecological system in agriculture) funded by the French Agency for Research and of the European FP7 project CANTOGETHER (grant agreement no. 289328). The authors thank the CANTOGETHER project coordinator, Pr. Philippe Leterme, for his help on this work, and the two anonymous reviewers for their help to improve this article.

\section{Supplementary Material}

For supplementary material accompanying this paper, visit http://dx.doi.org/10.1017/S1742170515000526

\section{References}

Acosta-Martínez, V., Bell, C.W., Morris, B.E.L., Zak, J., and Allen, V.G. 2010. Long-term soil microbial community and enzyme activity responses to an integrated cropping-livestock system in a semi-arid region. Agriculture Ecosystem Environment 137:231-240.

Altieri, M.A. 1999. The ecological role of biodiversity in agroecosystems. Agriculture Ecosystem Environment 74:19-31.

Armitage, D., Marschke, M., and Plummer, R. 2008. Adaptive co-management and the paradox of learning. Global Environmental Change 18:86-98.

Bell, L.W. and Moore, A.D. 2012. Integrated crop-livestock systems in Australian agriculture: Trends, drivers and implications. Agricultural Systems 111:1-12.

Bell, L.W., Moore, A.D., and Kirkegaard, J.A. 2014. Evolution in crop-livestock integration systems that improve farm productivity and environmental performance in Australia. European Journal of Agronomy 57:10-20.

Biggs, R., Schlüter, M., Biggs, D., Bohensky, E.L., BurnSilver, S., Cundill, G., Dakos, V., Daw, T.M., Evans, L. S., Kotschy, K., Leitch, A.M., Meek, C., Quinlan, A., Raudsepp-Hearne, C., Robards, M.D., Schoon, M.L., Schultz, L., and West, P.C. 2012. Toward principles for enhancing the resilience of ecosystem services. Annual Review of Environment and Resources 37:421-448.

Blom-Zandstra, M. and van Keulen, H. 2008. Innovative concepts towards sustainability in organic horticulture: Testing a participatory technology design. International Journal of Agricultural Sustainability 6:195-207.
Bonaudo, T., Bendahan, A.B., Sabatier, R., Ryschawy, J., Bellon, S., Leger, F., Magda, D., and Tichit, M. 2014. Agroecological principles for the redesign of integrated croplivestock systems. European Journal of Agronomy 57:43-51.

Botreau, R., Farruggia, A., Martin, B., Pomiès, D., and Dumont, B. 2014. Towards an agroecological assessment of dairy systems: Proposal for a set of criteria suited to mountain farming. Animal 8:1349-1360.

Bretagnolle, V., Gauffre, B., Meiss, H., and Badenhausser, I. 2011. The role of grassland areas within arable cropping systems for conservation of biodiversity at the regional level. In G. Lemaire, J. Hodgson, and A. Chabbi (eds). Grassland Productivity and Ecosystem Services. CABI, Wallingford, UK, p. 251-260.

Cabell, J.F. and Oelofse, M. 2012. An indicator framework for assessing agroecosystem resilience. Ecology and Society 17 (1): 18 .

Carof, M., Colomb, B., and Aveline, A. 2013. A guide for choosing the most appropriate method for multi-criteria assessment of agricultural systems according to decision-makers' expectations. Agricultural Systems 115:51-62.

Carvalho, P.C.F., Anghinoni, I., and Moraes, A. 2010. Managing grazing animals to achieve nutrient cycling and soil improvement in no-till integrated systems. Nutrient Cycling in Agroecosystems 88:259-273.

Chardon, X., Rigolot, C., Baratte, C., Espagnol, S., Raison, C., Martin-Clouaire, R., Rellier, J.-P., Le Gall, A., Dourmad, J. Y., Piquemal, B., Leterme, P., Paillat, J.M., Delaby, L., Garcia, F., Peyraud, J.L., Poupa, J.C., Morvan, T., and Faverdin, P. 2012. MELODIE: A whole-farm model to study the dynamics of nutrients in dairy and pig farms with crops. Animal 6:1711-1721.

Cutts, B.B., White, D.D., and Kinzig, A.P. 2011. Participatory geographic information systems for the co-production of science and policy in an emerging boundary organization. Environmental Science and Policy 14:977-985.

De Groot, R.S., Alkemade, R., Braat, L., Hein, L., and Willemen, L. 2010. Challenges in integrating the concept of ecosystem services and values in landscape planning, management and decision making. Ecological Complexity 7: 260-272.

Diacono, M. and Montemurro, F. 2010. Long-term effects of organic amendments on soil fertility. A review. Agronomy for Sustainable Development 30:401-422.

Díaz, S., Quétier, F., Cáceres, D.M., Trainor, S.F., PerezHarguindeguy, N., Bret-Harte, S., Finegan, B., PenaClaros, M., and Poorter, L. 2011. Linking functional diversity and social actor strategies in a framework for interdisciplinary analysis of nature's benefits to society. Proceedings of the National Academy of Sciences of the United States of America 108(3):895-902.

Drinkwater, L.E. and Snapp, S.S. 2007. Nutrients in agriculture: Rethinking the management paradigm. Advances in Agronomy 92:163-186.

Dumont, B., Fortun-Lamothe, L., Jouven, M., Thomas, M., and Tichit, M. 2013. Prospects from agroecology and industrial ecology for animal production in the 21 st century. Animal 7:1028-1043.

Duru, M. and Therond, O. 2014. Livestock system sustainability and resilience in intensive production zones: Which form of ecological modernization? Regional Environmental Change 15:1651-1665. doi: 10.1007/s10113-014-0722-9. 
Etienne, M. (ed.) 2014. Companion Modelling. A Participatory Approach to Support Sustainable Development. Springer, Dordrecht.

FAO 2006. Livestock's Long Shadow. FAO Collection: Environmental Issues and Options. Food and Agriculture Organization of the United Nations, Rome. p. 390.

Figuière, C. and Metereau, R. 2012. At the crossroads of industrial ecology and Syal. Advance the sustainability of a localized rural development. Communication at XXVIIIth ATM congress, Orléans, 11-13 June 2012 (in French).

Franzluebbers, A.J., Lemaire, G., de Faccio Carvalho, P.C., Sulc, R.M., and Dedieu, B. 2014. Toward agricultural sustainability through integrated crop-livestock systems: Environmental outcomes. Agriculture, Ecosystems, Environment 190:1-3.

Franzluebbers, A.J., Sawchik, J., and Taboada, M.A. 2013. Agronomic and environmental impacts of pasture-crop rotations in temperate North and South America. Agriculture, Ecosystems and Environment 190:18-26.

Gaba, S., Lescourret, F., Boudsocq, S., Enjalbert, J., Hinsinger, P., Journet, E.-P., Navas, M.-L., Wery, J., Louarn, G., Malézieux, E., Pelzer, E., Prudent, M., and OzierLafontaine, H. 2014. Multiple cropping systems as drivers for providing multiple ecosystem services: From concepts to design. Agronomy for Sustainable Development 35:607-623.

Garbach, K., Milder, J.C., Montenegro, M., Karp, D.S., and DeClerke, F. 2014. Biodiversity and ecosystem services in agroecosystems. Encyclopedia of Agriculture and Food Systems 2: 464-484. doi: 10.1016/B978-0-444-525123.00013-9.

Giller, K.E., Rowe, E.C., de Ridder, N., and van Keulen, H. 2006. Resource use dynamics and interactions in the tropics: Scaling up in space and time. Agricultural Systems 88:8-27.

Hendrickson, J.R., Hanson, J.D., Tanaka, D.L., and Sassenrath, G. 2008. Principles of integrated agricultural systems: Introduction to processes and definition. Renewable Agriculture and Food System 23:265.

Herrero, M., Thornton, P.K., Notenbaert, A.M., Wood, S., Msangi, S., Freeman, H.A., Bossio, D., Dixon, J., Peters, M., van de Steeg, J., Lynam, J., Parthasarathy Rao, P., Macmillan, S., Gerard, B., McDermott, J., Seré, C., and Rosegrant, M. 2010. Smart investments in sustainable food production: Revisiting mixed crop-livestock systems. Science 327:822-825.

Hill, S.B. 1998. Redesigning agroecosystems for environmental sustainability: A deep systems approach. System Research and Behaviour Science 15:391-402.

Horlings, L.G. and Marsden, T.K. 2011. Towards the real green revolution? Exploring the conceptual dimensions of a new ecological modernisation of agriculture that could 'feed the world'. Global Environmental Change 21:441-452.

Houdart, M., Bonin, M., and Compagnone, C. 2011. Social and spatial organisation-assessing the agroecological changes on farms: Case study in a banana-growing area of Guadeloupe. International Journal of Agricultural Resources, Governance and Ecology 9:15-30.

Klerkx, L., van Bommel, S., Bos, B., Holster, H., Zwartkruis, J. V., and Aarts, N. 2012. Design process outputs as boundary objects in agricultural innovation projects: Functions and limitations. Agricultural Systems 113:39-49.

Koohafkan, P., Altieri, M.A., and Gimenez, E.H. 2011. Green agriculture: Foundations for biodiverse, resilient and productive agricultural systems. International Journal of Agriculture Sustainability 10:61-75.

Kremen, C., Iles, A., and Bacon, C. 2012. Diversified farming systems: an agroecological, systems-based alternative to modern industrial agriculture. Ecology and Society 17(4): 44. http://dx.doi.org/10.5751/ES-05103-170444

Lemaire, G. 2007. Interactions entre systèmes fourragers et systèmes de grandes cultures à l'échelle d'un territoire. Intérêts pour l'environnement. Fourrages 189:19-32.

Lemaire, G., Franzluebbers, A., Carvalho, P.C. de F., and Dedieu, B. 2014. Integrated crop-livestock systems: Strategies to achieve synergy between agricultural production and environmental quality. Agriculture Ecosystem Environment 190:4-8.

Le Roux, R., Barbault, J., and Baudry, J. (coord.) 2008. Agriculture et biodiversité, valoriser les synergies. Expertise scientifique collective, synthèse du rapport, INRA.

Liebman, M. and Schulte, L.A. 2015. Enhancing agroecosystem performance and resilience through increased diversification of landscapes and cropping systems. Elementa: Science of the Anthropocene 3:1-7.

Lovell, S.T., DeSantis, S., Nathan, C., Olson, M.B., Ernesto Méndez, V., Kominami, H.C., and Erickson, D.L. 2010. Integrating agroecology and landscape multifunctionality in Vermont: An evolving framework to evaluate the design of agroecosystems. Agricultural Systems 103:327-341.

MacDonald, J.M., Ribaudo, M.O., Livingston, M.J., Beckman, J., and Huang, W. 2009. Manure Use for Fertilizer and for Energy. Administrative Publication No. (AP-037) 53 pp., June 2009. United States Department of Agriculture, Economic Research Service.

Martens, J.R.T. and Entz, M.H. 2011. Integrating green manure and grazing systems: A review. Canadian Journal of Plant Science 91(5):811-824.

Martin, G., Martin-Clouaire, R., and Duru, M. 2013. Farming system design to feed the changing world. A review. Agronomy for Sustainable Development 33:131-149.

Mazoyer, M. and Roudart, L. 2006. A History of World Agriculture from the Neolithic Age to the Current Crisis. Earthscan, New York, NY.

Meynard, J.M., Dedieu, B., and Bos, B. 2012. Re-design and codesign of farming systems: An overview of methods and practices. In I. Darnhofer, D. Gibbon, and B. Dedieu (eds). Farming Systems Research into the 21st century: The New Dynamic. Springer, Dordrecht. p. 407-431.

Millenium Ecosystem Assessment 2005. Ecosystems and Human Well-being: General Synthesis. Island Press, Washington.

Moraine, M., Duru, M., Nicholas, P., Leterme, P., and Therond, O. 2014a. Farming system design for innovative crop-livestock integration in Europe. Animal 8:12041217.

Moraine, M., Grimaldi, J., Murgue, C., Duru, M., and Therond, O. 2014b. Integrating crop and livestock activities at territorial level in the watershed of Aveyron river: From current issues to collective innovative solutions. In Proceedings of 11th European IFSA Symposium, 1-4 April 2014, Berlin, Germany. p. 1371-1384.

Nassauer, J.I. and Opdam, P. 2008. Design in science : Extending the landscape ecology paradigm. Landscape Ecology 23: 633-644.

Newig, J., Haberl, H., Pahl-Wostl, C., and Rotman, D.S. 2008. Formalise and non-formalised methods in resource 
management-knowledge and social learning in participatory processes: An introduction. System Practice and Action Research 21:381-387.

Pahl-Wostl, C. and Hare, M. 2004. Processes of social learning in integrated resources management. Journal of Community Applied Sociology and Psychology 14:193-206.

Peyraud, J.-L., Taboada, M., and Delaby, L. 2014. Integrated crop and livestock systems in Western Europe and South America: A review. European Journal of Agronomy 57: $31-42$.

Piñeiro, G., Paruelo, J.M., Oesterheld, M., and Jobbágy, E.G. 2010. Pathways of grazing effects on soil organic carbon and nitrogen. Rangeland Ecological Management 63(1): 109-119.

Poccard-Chapuis, R., Navegantes Alves, L., Mascarenha Grise, M., Bâ, A., Coulibaly, D., Ferreira, L.A., and Lecomte, P. 2014. Landscape characterization of integrated crop-livestock systems in three case studies of the tropics. Renewable Agriculture and Food Systems 29(3):218-229.

Poeschl, M., Ward, S., and Owende, P. 2012. Environmental impacts of biogas deployment- Part II: Life cycle assessment of multiple production and utilization pathways. Journal of Cleaner Production 24:184-201.

Power, A.G. 2010. Ecosystem services and agriculture: Tradeoffs and synergies. Philosophical Transactions of the Royal Society of London. Series B, Biological Sciences 365:2959-2971.

Randrianasolo, J., Lecomte, P., Salgado, P., and Lepelley, D. 2010. Modeling crop-livestock integration systems on a regional scale in Reunion Island: Sugar cane and dairy cow activities. Advances in Animal Biosciences 1:498.

Ratnadass, A., Fernandes, P., Avelino, J., and Habib, R. 2012. Plant species diversity for sustainable management of crop pests and diseases in agroecosystems: A review. Agronomy for Sustainable Development 32:273-303.

Rodríguez-Ortega, T., Oteros-Rozas, E., Ripoll-Bosch, R., Tichit, M., Martín-López, B., and Bernués, A. 2014. Applying the ecosystem services framework to pasturebased livestock farming systems in Europe. Animal 8:13611372.

Russelle, M.P., Entz, M.H., and Franzluebbers, A.J. 2007. Reconsidering integrated crop-livestock systems in North America. Agronomy Journal 99:325-334.

Ryschawy, J., Choisis, N., Choisis, J.P., Joannon, A., and Gibon, A. 2012. Mixed crop-livestock systems: An economic and environmental-friendly way of farming? Animal 6(10): 1722-1730.

Sabatier, R., Doyen, L., and Tichit, M. 2014. Heterogeneity and the trade-off between ecological and productive functions of agro-landscapes: A model of cattle-bird interactions in a grassland agroecosystem. Agricultural Systems 126:38-49.

Schiere, J.B., Ibrahim, M.N., and Van Keulen, H. 2002. The role of livestock for sustainability in mixed farming: Criteria and scenario studies under varying resource allocation. Agriculture, Ecosystems and Environment 90:139-153.
Schott, C., Mignolet, C., and Meynard, J. 2010. Les oléoprotéagineux dans les systèmes de culture: évolution des assolements et des successions culturales depuis les années 1970 dans le bassin de la Seine. Oilseeds and fats, Crops and Lipids 17:276-291.

Schouten, M.A.H., Van Der Heide, C.M., Heijman, W.J.M., and Opdam, P.F.M. 2012. A resilience-based policy evaluation framework : Application to European rural development policies. Ecological Economics 81:165-175.

Soussana, J.-F. and Lemaire, G. 2014. Coupling carbon and nitrogen cycles for environmentally sustainable intensification of grasslands and crop-livestock systems. Agriculture Ecosystem Environment 190:9-17.

Steyaert, P. and Jiggins, J. 2007. Governance of complex environmental situations through social learning: A synthesis of SLIM's lessons for research, policy and practice. Environmental Science and Policy 10:575-586.

Sulc, R.M. and Franzluebbers, A.J. 2014. Exploring integrated crop-livestock systems in different ecoregions of the United States. European Journal of Agronomy 57:21-30.

Sumberg, J. 2003. Towards a dis-aggregated view of crop-livestock integration in Western Africa. Land Use Policy 20: 253-264.

Swinton, S.M., Lupi, F., Robertson, G.P., and Hamilton, S.K. 2007. Ecosystem services and agriculture: Cultivating agricultural ecosystems for diverse benefits. Ecological Economics 64:245-252.

Tanaka, D.L., Karn, J.R., and Scholljegerdes, E. 2008. Integrated crop/livestock systems research: Practical research considerations. Renewable Agricultural and Food Systems 23:80-86.

Ten Napel, J., Van der Veen, A., Oosting, S.J., and Groot Koerkamp, P.W. 2011. A conceptual approach to design livestock production systems for robustness to enhance sustainability. Livestock Science 139(1):150-160.

Thornton, P.K. and Herrero, M. 2014. Climate change adaptation in mixed crop-livestock systems in developing countries. Global Food Security 3(2):99-107.

Vanwindekens, F.M., Stilmant, D., and Baret, P.V. 2013. Development of a broadened cognitive mapping approach for analysing systems of practices in social-ecological systems. Ecological Modelling 250:252-362.

Voinov, A. and Bousquet, F. 2010. Modelling with stakeholders. Environmental Modelling and Software 25:1268-1281.

Wardle, D.A., Bardgett, R.D., Klironomos, J.N., Setälä, H., Van der Putten, W.H., and Wall, D.H. 2004. Ecological linkages between aboveground and belowground biota. Science 304 : 1629-1633.

Wilkins, R.J. 2008. Eco-efficient approaches to land management: A case for increased integration of crop and animal production systems. Philosophical Transactions of the Royal Society of London. Series B, Biological Sciences 363:517-525.

Zhang, W., Ricketts, T.H., Kremen, C., Carney, K., and Swinton, S.M. 2007. Ecosystem services and dis-services to agriculture. Ecological Economics 64:253-260. 